\title{
Vision, Ambition, and Failure
}

\author{
Adolf Allwohn's practical take on Implementing an early \\ Intercultural and Interreligious Dialogue Organization \\ (Religiöser Menschheitsbund / 1921-1923)
}

\section{Introduction}

The history of the Western, modern interreligious dialogue (IRD) movement looks back at more than a century-long string of events, interventions, a multitude of initiatives and the establishment of various organizations that were, and still are, dedicated to fostering interreligious dialogue. In a highly globalized world, the interest in studying these interreligious relations and interactions between religious communities spark wide public and scholarly interest. Whereby "dialogue" is only one form of relational engagement next to conversation, cooperation, collaboration and everyday interaction, just to name a few. ${ }^{1}$ As the question of how representatives of religions interact and how the religious other is perceived in this interaction in a plural world is a question that is not just of scholarly interest but also of interest to members of a growing number of religiously heterogeneous local communities. As a result of this paradigm shift those who participate find themselves being part of a shift towards plurality and changing perceptions of their own exclusivism and mere tolerance towards increased acknowledgement and validity of other religions.

While dialogue between religions has long-standing histories, the 1983 Parliament of World Religions in Chicago is widely accepted as a starting date of the modern development in interreligious relations while being mainly a shift within Western Christianity to rethink its relations to other religions beyond missions' endeavours. The RMB was part of this first wave of organizations experimenting in how these newly rethought relations might be applied. ${ }^{2}$

By dedicating the volume at hand to different voices and visions of the various past and present initiatives, this anthology contributes to the interreligious

1 See: Catherine Cornille, ed., The Wiley-Blackwell Companion to Inter-Religious Dialogue (Hoboken and West Sussex: John Wiley \& Sons, 2013), 1-2.

2 See: David Cheetham, Douglas Pratt, David Thomas, eds., Understanding interreligious Relations (Oxford: University Press, 2013), 1-3.

Ә OpenAccess. (c) 2021 Verena E. Kozmann, published by De Gruyter. (cc))BY-NC-ND This work is licensed under the Creative Commons Attribution-NonCommercial-NoDerivatives 4.0 License. 
dialogue movement ${ }^{3}$ in general and - by including Rudolf Otto's Religious Union of Humankind, in the following abbreviated as the RMB, ${ }^{4}$ it highlights not only general dialogue-dimensions but goes beyond it by focusing on the subjects of justice, moral, and peace. In accordance with the publication's overall aim to focus on informal key-moments recorded in the organizations' archives, such as debates and discussions during the organizations' founding moments, this chapter examines the largely unpublished RMB archive material of its first and only general secretary Adolf Allwohn.

By shedding light on the tensions between the organization's theoretical foundation and the practical implementation of the RMB, this paper explores the RMB's failure despite it being a timely endeavour and sheds light on the question: What were the roles of Adolf Allwohn and Rudolf Otto in this context?

The paper starts its examination in the founding year, 1921, as a starting point and outlines the RMB's vision through the introduction of its founder, Rudolf Otto, as its theoretical (and practical) starting- and endpoint of the RMB. The focus then shifts towards the RMB's general secretary, Adolf Allwohn, who was instrumental in the day-to-day business of the RMB and whose detailed notes and correspondence are critical sources for tracing the RMB's everyday business. The paper examines how the implementation of the RMB failed by looking at Otto's and Allwohn's respective biographies, Allwohn's relationship to Otto, Allwohn's role within the RMB and the challenges he faced until leaving his position as its general secretary.

\footnotetext{
3 As said above the emergence of the modern interreligious dialogue movement is commonly linked to the 1893 World's Parliament of Religions, which took place in Chicago and was part of the Chicago World Fair of that year. The emphasis of this event, according to the organizers, was to foster cooperation between different religious communities. However, according to Moyaert this event also set the tone and main challenge for the modern interreligious dialogue movement, then and now: the tension between identity and otherness. For further details, see: Moyaert, Marianne, "Interreligious Dialogue," in Understanding Interreligious Relations, ed. David Cheetham, Douglas Pratt and David Thomas (Oxford: Oxford University Press, 2013): 193-194.)

4 The abbreviation "RMB” derives from the alliance's German name Religiöser Menschheitsbund and is found throughout English and German literature on Rudolf Otto and the Religious Humanity Alliance. Rudolf Otto used the name and abbreviation first in his introductory article on RMB: Rudolf Otto, "Religiöser Menschheitsbund neben politischem Völkerbund,” Die Christliche Welt 34 (1920): 133-135.
} 


\title{
2 Adolf Allwohn: Identifying the Margin and the Center
}

In identifying main and marginal agents and putting them in context, this chapter follows a historical anthropological approach as reflected by Brian Axel,

\begin{abstract}
it may be said that the textual practices of historical anthropology operate from the margins - [...] however it should not be understood that either the topics under investigation, or the scholars involved in the inquiry, are marginal. In fact, in many cases, they are quite central. Nor should it be taken to imply that historical anthropology only studies marginal events or marginalized people [...]. On the contrary, historical anthropology, very powerfully, develops inquiries into the non-eventful, [...]. In other words, historical anthropology constitutes new centers of inquiry, just as it demonstrates the powerful positionality of the margins right at the center. ${ }^{5}$
\end{abstract}

This approach is considered appropriate in the study of Adolf Allwohn, who remained at the margins as the general secretary of the RMB despite the fact that he was predominantly responsible for organizing the RMB's everyday business. The question is: How can Adolf Allwohn's role be interpreted in the RMB's failure to establish a lasting foundation? It is my belief that offering an interpretation of the surviving documents and papers of the RMB's general secretary provides an additional perspective and thus may contribute to the overall knowledge about the RMB's implementation endeavour. One that will help us come to terms with potential answers to this question. Allwohn's notes and correspondence contain information on the settings, places and issues that may help to trace why the implementation of the RMB failed so quickly after its inauguration. ${ }^{6}$

Whereby "failure" itself is examined, as a source for potentially better understanding of the past doings and its possible influence on future IRD endeavours. As such, failure itself means to set a goal, act, and aspire, marks initiative, courage, action and intent. As preconditions for failure include progress and change as well as desire and expectations. Because the paradox of failure is that we can only fail if we strive to do. ${ }^{7}$

5 Brian K. Axel, ed., From the Margins: Historical Anthropology and its Futures (Durham N.C: Duke University Press, 2002), 2-3.

6 Amanda Coffey, “Analysing Documents," in The SAGE Handbook of Qualitative Data Analysis, ed. Uwe Flick (London: Sage, 2014): 370.

7 See: Howe, Cymene and Stephanie Takaragawa, Failure: Theorizing the Contemporary: http:// culanth.org/fieldsights/failure (accessed: 24.5.2020). 
In the following Rudolf Otto and Adolf Allwohn, and their relationship to the RMB are introduced, by first outlining Rudolf Otto's vision for the RMB followed by introducing Adolf Allwohn and unpacking his role within the RMB followed by unpacking assumed key issues of its rapid failure.

\subsection{Archival Research}

In order to be able to trace the RMB's peak a century ago, it was necessary to go back to the archives and to make use of the existing Rudolf Otto-archive at the Philips-University in Marburg, Germany - the very same university where Otto taught as a professor of Systematic Theology from 1917 till 1929, the year of his retirement. Due to historical reasons, the Otto archive is currently divided between two locations within the university library: the main university library and the Religionskundliche Sammlung. The main documents in relation to the RMB, including Allwohn's documents, are archived in the latter location.

Otto was a passionate writer. Throughout his life, he was an enthusiastic user of the prevailing streams of communication, which he relied on to maintain his global social network. He exchanged numerous letters, postcards and, on rare occasions, also telegraphs with colleagues, family and friends. Although he - like many others in his time - wished that his correspondence be destroyed after his death, a significant part of it is preserved. However, there were certain limitations to consulting these remaining primary sources, since they were not digitized, and Otto's handwriting created a legibility challenge in reading these documents.

\subsection{The Allwohn-Archive}

The Otto archive contains Adolf Allwohn's correspondence and notes that pertain to his function at the RMB. Allwohn was in his mid-twenties when he became the RMB general secretary. He worked in this role while he was finishing his studies to become a pastor, working on his doctoral thesis and settling down in his private life as a newlywed. He started his work as general secretary in early 1921 and helped in the organization of the RMB's only conference in 1922. But then, in 1923, his involvement rapidly declined, resulting in ceasing to work for the organization for reasons we can only speculate about. Despite his sudden withdrawal from the RMB, Allwohn's papers and correspondences are important instruments aiding to help understand the RMB's dynamics at its founding mo- 
ment and initial stages, as well as the conjectures regarding the organization's decline and ultimate failure.

It may be argued that Allwohn's documents are especially attractive due to their raw, untouched, and unpolished state (which is in conspicuous contrast to Otto’s ‘cleaned-up’ appearing papers). Allwohn relinquished his notes and correspondences to the Otto Archive in 1952. In the still existing cover letter accompanying his RMB materials sent to the Otto Archive, Allwohn wrote to the Director of the Religionskundliche Sammlung, "I just sent the RMB files, which I was still storing, to your institute. I had no time to look through the materials beforehand. Surely, many of these papers may be recycled. Other materials may merge with the Rudolf Otto estate". ${ }^{8}$

Examining the Adolf-Allwohn papers unveils personal notes, jottings and fragmented thoughts. Sometimes they are even written on used marriage certificates (most probably due to a shortage of paper at the time), sometimes they are written with pencil, sometimes in ink, mostly unsigned and undated. Opening this box and looking at its contents, it seems that the museum's director at the time Heinrich Frick decided to keep Allwohn's estate in one piece and added it to the Otto archive as-is. Now, decades later, these materials have turned out to be a source of potentially important information about the founding time of the RMB.

\subsection{Additional Sources: Expert Interviews}

In addition to the above-mentioned primary sources, I was able to conduct several conversations with Rudolf Otto experts during the five-week research stay in Marburg. The experts consulted are Jörg Lauster and Peter Schütz, Philipps-University, and Ulrich Rosenhagen, University of Wisconsin, USA, a visiting researcher to Marburg. The main informant, however, was Martin Kraatz, who was long-standing Director of the Religionskundliche Sammlung at the University of Marburg, who agreed to provide me with his expert knowledge throughout several meetings as well as one lengthy telephone conversation.

8 "Soeben habe ich die Akten des Religiösen Menschheitsbundes, die ich immer noch aufbewahrt hatte, an dein Institut abgesandt. Da ich keine Zeit dazu hatte, habe ich sie nicht durchgesehen. Sicherlich kann vieles zum Altpapier wandern. Anderes wird wohl dem Nachlass Rudolf Ottos einverleibt werden." See: OA 1754/Adolf Allwohn/no title/14.01.1952/Rudolf OttoArchive, Religionskundliche Sammlung, Philipp-University Marburg. Translated by the author. (The boxes materials are quoted according to the guidelines of the respective archives.) 


\section{The Founder Rudolf Otto: The RMB's Well-Connected Theorist}

The RMB was established in 1921, in post-war Germany by the German theologian, Rudolf Otto. Today, Otto is considered to be one of the first and most influential Religious Studies' scholars in Germany and is still well known to a wide audience through his magnum opus The Idea of the Holy (1917). ${ }^{9}$ Like many other intellectuals of his time, Otto lived through WWI and its aftermath, witnessing suffering, social injustice and violence, which is believed to have influenced his writings. He believed that there is a need for an independent, international and interreligious forum to dialogue on shared ethical issues to the benefit of all people beyond religions. In line with this understanding, the purpose of the RMB was to work alongside the then newly established League of Nations, founded in 1920 as part of the Paris Peace Conference. According to Otto, the establishment of the League of Nations was not enough to cover the world's moral needs. Otto perceived the League of Nations as a mere political organization serving the interest of the prevailing politicians. Thus, the RMB was, in his opinion, needed to unite the fragmented post-war world and the logical addition to the League of Nations. Otto not only wanted to bring representatives of different world religions together but also hoped to give these representatives a shared platform to get in contact and think together about how to build future peaceful societies. As Choi summarizes, he viewed religious institutions and the state in a symbiotic relationship; While the state should respect the authority of religions, religions should contribute to the goodwill of the state by offering their share in raising the overall morale of the nation and ensuring the further developments of social norms and shared values. ${ }^{10}$

In an essay, published in 1920, just a year before the RMB was founded Otto states,

we hope that the nations' shared misery today should finally teach people what religion and ethics should have taught them already: all countries and peoples have to reflect to-

9 Jörg Lauster, Peter Schütz, Roderich Barth and Christian Danz, eds., Rudolf Otto: Theologie Religionsphilosophie - Religionsgeschichte (Berlin: De Gruyter, 2014).

10 See: Jeong Hwa Choi, Religion als 'Weltgewissen': Rudolf Ottos Religiöser Menschheitsbund und das Zusammenspiel von Religionsforschung und Religionsbegegnung nach dem Ersten Weltkrieg (Zürich/Berlin: LIT-Verlag, 2013), 39. 
gether on the big questions of mankind and on peaceful collaboration. Politics alone cannot do that. ${ }^{11}$

This statement summarizes the RMB founder's vision for the organization. Its principles include: a) providing a platform for the representatives of world religions to discuss issues of mankind; b) providing a forum for the representatives of world religions to discuss ethics; $c$ ) being an independent voice alongside the voice of political powers; d) contributing to a fraternal and peaceful communal life; while e) respecting religious and cultural differences. ${ }^{12}$ According to Otto, these principles should culminate in the formation of the Weltgewissen (world consciousness), for which the RMB would function as an umbrella organization, fostering the participation of countless independent local delegations and groups around the world. ${ }^{13}$

As stated by the Rudolf Otto expert Kraatz, "the story of the RMB is inextricably linked with the person Rudolf Otto," ${ }^{14}$ thus demonstrating the importance of studying Rudolf Otto and the historical and intellectual context of his life and career to understand the organization. Otto, according to Kraatz and Lauster, is the most important figure in the history of the RMB, even though the organization has not been a recent research focus within the Otto scholarship. ${ }^{15}$ It was only in 2010 (published in 2013), when Jeong Hwa Choi finished her dissertation on the RMB, that the organization was put into scholarly historical focus. Choi is the first scholar to have published, a monograph on the RMB. ${ }^{16}$ Her contribution goes hand-in-hand with the current re-evaluation of Rudolf Otto's legacy, as seen in a recent major publication and an international congress held in 2012 at the

11 "Die gemeinsame Not der Völker von heute wird sie [die Menschheit], so hoffen wir, endlich lehren, was Religion und Ethik sie längst hätten lehren sollen: das (sic!) die Menschheit aller Länder und Völker sich besinnen muss auf Zusammengehen, auf gemeinschaftlich zu leitende große Gemeinschaftsaufgaben, auf friedbrüderliches Zusammenwirken und -streben. Politischer Zusammenschluss allein kann das nicht leisten." Otto, "Religiöser Menschheitsbund neben politischem Völkerbund," 133-135. Translated by the author.

12 See: OA1282 Rudolf Otto/Weltgewissen und die Wege dazu (Erstes Mitteilungsblatt des Religiösen Menschheitsbundes, interreligiöse Arbeitsgemeinschaft zur Versittlichung des Volks- und Völkerlebens/no date/Rudolf Otto-Archive, Religionskundliche Sammlung, Philipp-University Marburg.

13 See: Lauster, Schütz, Barth and Danz, Rudolf Otto, 1-28.

14 Conversation with Martin Kraatz on Rudolf Otto, 17.07.2014, Marburg/Germany.

15 Conversation with Martin Kraatz on Rudolf Otto, 17.07.2014, Marburg/Germany; Conversation with Jörg Lauster on Rudolf Otto, 17.7.2014, Marburg/Germany. See: e. g. Choi, Religion als 'Weltgewissen', 7-10.

16 Choi, Religion als 'Weltgewissen'. 
Philipps-University Marburg. ${ }^{17}$ This conference gathered international experts in order to conduct contemporary readings of Rudolf Otto and his thought to explore his impact on current theology and interreligious dialogue.

In terms of historical context, it is necessary to point out that the RMB was by no means unique in its approach. After WWI, until the emergence of the Weimar Republic in the 1930s, many organizations similar to the RMB appeared on the national level in Germany, as well as on the international stage. Like the $\mathrm{RMB}$, these organizations promoted dialogue and peace. For instance, the English branch of the League of Nations established the Committee of Religion and Ethics in 1921, with the intention of establishing an organization similar to the RMB. Also worth mentioning are the League of Religions founded in 1919 in England, and the Italian association of fostering religious and moral awakening, Associazione per il progresso morale e religioso, just to name a few. ${ }^{18}$ Otto was in contact with many of these organizations, ${ }^{19}$ and it is assumed that he wished to make his own contribution to that field by founding the RMB and vice versa these international contacts certainly strengthened the RMB's international network and initially attracted many religious representatives to its activities.

Rudolf Otto (1869-1937) may be described as one of the German public intellectuals of his time. Born and raised in Germany he experienced WWI from inside Germany - an experience, which doubtlessly left a long-lasting impression on Otto's intellectual development and thinking. In studying Rudolf Otto, we encounter an admirably prolific figure: a Lutheran pastor, world traveller, politician, writer, professor of Systematic Theology, a pioneer in the field of Religious Studies and founding figure of the RMB. ${ }^{20}$ As mentioned above, he became wellknown in the international arena through his magnum opus, The Idea of the Holy, first published in 1917 and translated into more than 30 languages. $^{21}$ This publication became a classic and still is acknowledged by theologians and religious studies' scholars today. The notoriety he gained through this publication helped him to widen his social network and enabled him to attract attention to his projects including the RMB. ${ }^{22}$

17 Lauster, Schütz, Barth and Danz, Rudolf Otto.

18 See: Choi, Religion als 'Weltgewissen', 102-8.

19 See: Choi, Religion als 'Weltgewissen', 102-8.

20 See: Choi, Religion als 'Weltgewissen', 13-20, 28-32, 58-59.

21 Rudolf Otto, Das Heilige: Über das Irrationale in der Idee des Göttlichen und sein Verhältnis zum Rationalen (Breslau: Trewendt und Garnier, 1923).

22 See: Choi, Religion als 'Weltgewissen', 2013:45. 
Let us, however, step back for a moment and examine a moment of Otto's early life that may have contributed to the later RMB vision. In 1913, inspired by his travels and political activities, Otto participated in an international conference in Paris, Weltkongress für freies Christentum und religiösen Fortschritt (World Congress for a Free Christendom and Advancement in Religion). ${ }^{23}$ This congress tackled issues such as the relationship between Christians and non-Christians. Otto was invited to this conference to give a paper on the question "is a universal religion desirable and possible?"24 There, he met Martin Rade (1857-1940) and Friedrich Siegmund-Schulze (1885-1969), who continued to inspire Otto long after the conclusion of the conference. ${ }^{25}$ According to Choi, this event was the initial point of inspiration for founding the RMB eight years later. ${ }^{26}$ During these years, Otto developed the following three RMB principles: a) All religions are equal; b) the state should respect religions' authority, while religion, in turn, should contribute to finding answers to ethical and political questions; and c) ethical norms and developments on national and international levels cannot be achieved without taking into consideration religion and politics. As he wrote: "Religion and state have to be in a symbiotic relationship in order to boost and advance the moral of the nation and foster social equity and peace between the nations." 27 Otto had the vision that representatives of all world religions work together to complete what political platforms, like the League of Nations, could not fulfill, that is, working directly for the people and communities, not for the people in political power.

Using his wide social network, and thanks to several essays he published in the journal Christliche Welt on the RMB, Otto was able to attract and motivate several key figures including representatives of world religions like Rabindranath Tagore (India) and Ryohon Kiba (Japan) and intellectuals inside and outside of Germany, like Heinrich Frick, Martin Rade, Kristian Schjelderup, Richard

23 Frank Obergethmann, "Rudolf Ottos' 'Religiöser Menschheitsbund': Ein Kapitel interreligiöser Begegnung zwischen den Weltkriegen”, Zeitschrift für Religionswissenschaft 6 (1998): 79-106, here: $79-80$.

24 See: Obergethmann, “Rudolf Ottos' 'Religiöser Menschheitsbund': Ein Kapitel,” 80; Choi, Religion als 'Weltgewissen', 39.

25 See: Choi, Religion als 'Weltgewissen', 38.

26 See: Choi, Religion als 'Weltgewissen',38.

27 "eine von Diplomatie unabhängige, freie Gemeinschaft die grosse Fragen zwischenvölkischer Beziehungen, die Aufgaben allgemein menschlicher sittlicher Kultur im Zusammenwirken der gesamten Kulturmenschheit, [...] die Aufgabe, eine öffentliche Meinung der Welt zu bilden und das Weltgewissen zu wecken,” Rudolf Otto, “Vom Religiösen Menschheitsbunde,” Die Christliche Welt 34 (1920): 477-78. Translated by the author. 
Wilhelm, Wilhelm Gundert and Emil Schiller. ${ }^{28}$ Choi describes this key factor in implementing the RMB, "interested people from many different countries came [...] to Marburg to become his [Otto's] students, he was the centre of a developing network which included many public personalities who helped to make the organization known." ${ }^{29}$ Otto wanted to implement the RMB's vision on the ground by encouraging these key-figures to establish independent local groups which was thought to help multiply the quantity of local groups and spread them easily. However, it was also in need of someone to manage the everyday business, a general secretary.

\subsection{The RMB's First and Only General Secretary, Adolf Allwohn}

In 1921, Adolf Allwohn was only twenty-eight years old when he joined the RMB and became its first (and only) General Secretary. He seems to have been highly ambitious and well-educated, studied Theology in London, Oxford, Leipzig, Berlin and finally in Giessen (where he completed his final exams in 1919 and 1920). After finishing his studies, Allwohn began his career as a pastoral assistant and later continued his education to become a Lutheran pastor in Kirtorf, Germany from 1922-1926 when he was ordained. In parallel, he completed a Ph.D. in Theology in 1923 and a second doctorate in Philosophy in $1924 .^{30}$

Knowing these biographical details, one could argue that Adolf Allwohn was highly qualified when he became the general secretary of the RMB in early 1921 . However, his motives to join the RMB are unknown. However, he held a great deal of admiration for Otto, and has been influenced by Otto's writings, which he expressed in a letter to Otto dated April 28, 1921, "I want to use this occasion to thank you cordially for all and everything your book 'The Idea of the Holy' gave me. Your devoted, Adolf Allwohn." ${ }^{31}$ While Otto and Allwohn worked together to benefit the RMB their relationship remained professional.

28 See: Choi, Religion als 'Weltgewissen', 60-88.

29 See: Choi, Religion als 'Weltgewissen', 58.

30 See: Choi, Religion als 'Weltgewissen', 60-62.

31 "Ich möchte Ihnen bei dieser Gelegenheit herzlich danken für all das was mir Ihr Buch "Das Heilige” gegeben hat. Ihr sehr ergebener Adolf Allwohn.” See: OA1760 by Adolf Allwohn/no title/ 28.04.1921/Rudolf Otto-Archive, Religionskundliche Sammlung, Philipps-University Marburg. Translated by the author. 


\subsection{A General Secretary with a Vision: Allwohn's Ambitions}

While Otto referred to Allwohn as "Pastor" or "Secretary"32, Allwohn himself signed official papers as the RMB's "General Secretary"33 or "General Manager." ${ }^{34}$ He states in his notes

My allocated role is not restricted to merely administrative duties but goes far beyond and is primarily a religious call (to activate others). I feel to have been called by God to do so. I have the impression that God showed me a way to fulfil my innermost calling. [...] I was looking for an occupation like this, which is leading me beyond the function as a church's employee. $^{35}$

This indicates that his role at the RMB was more than being a merely administrative employee, however, a clear-cut job description is not recorded. As the above-cited quotation shows, Allwohn had great expectations in his new position and he aspired to make a difference beyond his community, putting energy, time and thought into this goal. Moreover, Allwohn saw in his new position a call to fulfill God's will and to serve beyond the circles of his congregation. He saw his role as a missionary to serve God beyond the borders of the church, his interest was to serve religiosity itself. Furthermore, he recognized the potential political power inherent to a project like the RMB:

The RMB does not underestimate the power of realpolitische [pragmatic] realities in the context of historic events, it [the RMB] is convinced that belief and conscience are equally, if not even stronger realities. These inner powers are asking to attract attention and consideration. They [the inner powers] can no longer tolerate that the course of the world is governed solely through money and brutal violence. The inner life starts now to gain more and

32 See: OA1792, by Adolf Allwohn/no title/no date/Rudolf Otto-Archive Religionskundliche Sammlung, Philipps-University Marburg.

33 See: OA1785, by Adolf Allwohn/ Vom Religiösen Menschheitsbund/no date/Rudolf Otto-Archive Religionskundliche Sammlung, Philipps-University Marburg.

34 See: OA1794, by Adolf Allwohn/no title/no date/Rudolf Otto-Archive Religionskundliche Sammlung, University Marburg; OA1795, by Adolf Allwohn/no title/no date/Rudolf Otto-Archive Religionskundliche Sammlung, Philipps-University Marburg.

35 "Die mir zugedachte Tätigkeit sich durchaus nicht im organisatorischer Arbeit erschöpfen sondern hauptsächlich in einem religiösen Aufrufern bestehen sollte, fühlte ich mich von Gott zu diesem Werk berufen, zumal. Unt Ich stehe so unter dem starken Eindruck, dass Gott mir hier einen Weg gezeigt hat, auf dem ich meinem innersten Beruf nachkommen kann. [...] Ich war schon lange auf der Suche nach einer Tätigkeit, die mich über das Amt eines Angestellten der Kirche hinausführen könnte." See: OA 1758, by Adolf Allwohn/no title/no date/Rudolf Otto-Archive Religionskundliche Sammlung, Philipps-University Marburg. Translated by the author. 
more strength so that it starts to enforce its influence in the outer life and that its principals are becoming leading principals to restructure the world. [...] He [the RMB] is counting on those who, considering their faith and consciousness are not willing to stay put and leave the world to the devil. ${ }^{36}$

As general secretary he attended to many matters on the ground like sending invitations, taking care of recruiting new members, as well as going on lecture tours and managing membership contributions. Allwohn's everyday duties included travelling through Germany to visit local groups and advertising initiatives, recruiting new members and organizing local group meetings:

What is unifying the confessions? Announcement of the Religious Union of Humankind local group Offenbach, Friday the $13^{\text {th }}$ of January $19218 \mathrm{pm}$ in the gym of the Goethe school $[\ldots] .{ }^{37}$

Dear Ms. Dillenberger! Please, produce 50 copies of the attached invitation and send them to me Saturday evening. In case this is not possible I will collect them from you on Sunday morning between 11am and 1pm. But I ask you urgently to finish them until then. ${ }^{38}$

local group in Marburg /Darmstadt; [...] I Hamburg: visited youth - youth ring and confessional mixed; [...] II Berlin: own evening, peace society religion and peace of nation, radical ethic; Catholics/Jews/Culture ring/ religious socialists/ Quakers ${ }^{39}$

36 "Der R.M.B. verkennt nicht die Macht der realpolitischen Wirklichkeiten für das geschichtliche Geschehen, er ist aber überzeugt, dass Glauben und Gewissen ebenso starke wenn nicht noch stärkere Wirklichkeiten sind. Diese inneren Mächte verlangen jetzt gebieterisch Beachtung und Berücksichtigung. Sie können es nicht länger dulden, dass der Weltlauf allein durch das Geld und die brutale Gewalt beherrscht wird. Das innere Leben fängt jetzt an, so stark zu werden, dass es sich auch im ausseren Leben Geltung verschaffen und dass es seine Grundsätze sogar zum leitenden Prinzip einer Neugestaltung der Welt erheben muss. - [...] Er rechnet auf diejenigen, die es um Glaubens- und Gewissens willen nicht aushalten, stille zu sitzen und die Welt dem Teufel zu überlassen.” See: OA1785, by Adolf Allwohn/ Vom Religiösen Menschheitsbund/no date/Rudolf Otto-Archive Religionskundliche Sammlung, Philipps-University Marburg. Translated by the author.

37 "Was eint die Konfessionen? Kundgebung der Ortsgruppe Offenbach des Religiösen Menschheitsbundes am Freitag, 13. Jannuar 1921 abends 8 Uhr in der Turnhalle der Goetheschule Bernardstrasse [...].” See: OA1768, by Adolf Allwohn/no title/no date/Rudolf Otto-Archive Religionskundliche Sammlung, Philipps-University Marburg. Translated by the author.

38 "Sehr geehrte Frau Dillenberger! Ich bitte Sie, umgehend 50 Abzüge von umstehender Einladung zu machen und sie mir am Samstag Abend zuzuschicken. Wenn Ihnen das nicht möglich ist, dann werde ich am Sonntag Vormittag zwischen 11 und 1 Uhr zu Ihnen kommen, und mir die Karten selbst abholen. Ich bitte Sie aber dringend, sie bis dahin fertig zu stellen. [...]" See: OA1789, by Adolf Allwohn/no title/January $13^{\text {th }}, 1922$ /Rudolf Otto-Archive Religionskundliche Sammlung, Philipps-University Marburg. Translated by the author.

39 "Ortsgruppe in Marburg/Darmstadt; I Hamburg: besucht Jugend - Jugendring auch konfessionell gemischt; [...] II Berlin: eigener Abend, Friedensgesellschaft Religion und Völkerfrieden, 
These activities shared one major goal, that is, the acquisition of new members. According to Choi, Allwohn was the most active and committed person in the first phase of the RMB. ${ }^{40}$ However, considering the ambitions for international expansion, the RMB drew relatively modest interest towards potential membership among its German and international circles. After Allwohn's withdrawal, no other administrator followed often to continue the multitude of tasks Allwohn was balancing being a representative figure, being often the first contact for new members and thus taking care of the development of the RMB as well as the everyday administrative work.

\title{
3 The RMB's Principals: Guidelines Needed
}

Allwohn embraced his role as general secretary. He not only followed Otto's instructions but also applied his own thoughts about the organization's meaning and use. His notes reveal informative fragments on this thought processes,

\begin{abstract}
What is the task of the religious community, of the moral consortium? What is the task of religious communities and moral consortiums: Religious communities have huge, moral responsibilities-would be better for culture as well-there are also the big, international questions included: [...] imperialism, every moral assignment has cosmic aspects of [having influence] on the culture 2) The relationship of the R.M.B. to related ambitions. Who should become a member in the R.M.B. 3) Sceptics? Channeling destiny as God's personnel [...] wanting religious-moral public conscience - church is not strong enough - [...] moral achievement. ${ }^{41}$
\end{abstract}

The above excerpt indicates the direction of Allwohn's considerations on the RMB. He concluded that the system of religious communities put the commun-

radikale Ethik; Katholiken/Juden/Kulturring/religiöse Sozialisten/Quäker.” See: OA1783, by Adolf Allwohn/no title/no date/Rudolf Otto-Archive Religionskundliche Sammlung, PhilippsUniversity Marburg. Translated by author.

40 Choi, Religion als 'Weltgewissen', 60.

41 "Was ist die Aufgabe der religiösen Gemeinschaft, [der] sittlichen Arbeitsgemeinschaft: Religionsgemeinschaften haben grosse sittliche Aufgaben, Arbeiten auch Kult besser stellen, darunter auch Die [sic!] grossen internationalen Fragen: [...] Imperialismus, jede sittliche Aufgabe ist kosmischer Aspekt von Kulturmenschheit; 2) Das verhältnis [sic!] des R.M.B. und verwandten Bestrebungen. Wer soll dem R.M.B. beitreten; 3) Skeptiker. Schicksal lenken als Mitarbeiter Gottes [...] von den guten Werken; religiös sittliches wollen allgemeines Gewissen - Kirche nicht mehr wirkungskräftig - [...] sittlicher Leistung.” See: OA1784 by Adolf Allwohn/no title/ no date/Rudolf Otto-Archive, Religionskundliche Sammlung, Philipps-University Marburg. Translated by the author. 
ities in competition and cooperation at the same time. Therefore, in his opinion, the aim should have been to strengthen the general welfare and find common ground in relation to shared culture, the moral state of the community, as well as public networking of the involved denominations. All these elements must ultimately serve the purpose of building up a shared moral code and understanding. Subsequently, these developments would eventually lead to the establishment of a shared Weltgewissen and would further lead to the establishment of moral conscience in leaders and public figures, inspire and lead others in the community. ${ }^{42}$

Beyond these aspirations, Allwohn shared Otto's conviction that the RMB must also find resonance at the international level and that sceptics must be actively convinced about the project. Allwohn believed that the church alone was neither effective nor strong enough to lead this organization. ${ }^{43}$ In his opinion, the RMB was more than a practical prerequisite and a child born out of ideals and enthusiasm. Religion, according to Allwohn, is interchangeable and, in the end, what is considered to be holy is not really important: "Whether I consider holy persons, holy things, heaven or earth, Jesus or Buddha, moral commandments or acts of God. It is not important what I adore, but it is important that whatever is considered holy must be worth it." ${ }^{44}$

According to Allwohn the idea of being moral has to connect to the dimension of the experience of the holy, that is, the religious feeling, which, in return, must be the feeling of being good and, finally, it - the holy - must direct how one lives. These moral activities should reach individual private lives, family lives, as well as political lives and beyond that communal life before they finally reach the state. The problem, according to Allwohn is that there is not enough awareness to allow for public life to be arranged by the individual's moral convictions. ${ }^{45}$

42 See: OA1785 by Adolf Allwohn/ Vom Religiösen Menschheitsbund/no date/Rudolf Otto-Archive Religionskundliche Sammlung, Philipps-University Marburg.

43 See: OA1784 by Adolf Allwohn/no title/no date/Rudolf Otto-Archive; OA1783 by Adolf Allwohn/no title/no date/Rudolf Otto-Archive, Religionskundliche Sammlung, University Marburg; OA1759, by Adolf Allwohn/no title/no date/Rudolf Otto-Archive, Religionskundliche Sammlung, Philipps-University Marburg.

44 "ob ich heilige Personen oder heilige Dinge, Himmel oder Erde, Jesus oder Buddha, sittliche Gebote oder Naturereignisse. Was ich verehre, das [...], es muss aber immer so sein, dass es wert ist, für heilig gehalten zu werden.” See: OA1783, by Adolf Allwohn/no title/no date/Rudolf OttoArchive, Religionskundliche Sammlung, Philipps-University Marburg. Translated by the author. 45 See: OA1783, by Adolf Allwohn/no title/no date/Rudolf Otto-Archive; OA1759, by Adolf Allwohn/no title/no date/Rudolf Otto-Archive, Religionskundliche Sammlung, Philipps-University 
Allwohn interpreted, translated and further developed the RMB's ideas and principals - as introduced by Otto - into the day-to-day activities and realities he found. Thus, he was actively involved in contributing to implementing RMB principles.

It is undocumented whether Allwohn's interpretations were exposed to scrutiny and revision by Otto. However, the above-examined efforts by Allwohn to apply Otto's framework to the RMB's operation show that there was a great need for the development of a clear-cut implementation guideline for the RMB.

\section{Allwohn's Endeavor towards Implementation}

Examples of these negotiations discussed in local groups are demonstrated in the following quotes, which Allwohn wrote in formal letters addressed to Otto:

I thank you dearly for your welcome greetings in the name of the local group. - We have had a session some days ago and pronounced the RMB's aims and tasks. In the process some wishes and plans for the RMB's directions got pronounced, which I was asked to communicate to you. ${ }^{46}$

Dear Professor! The local group was missing a good reason to use the name Religious Union of Humankind. First, it was thought that the alliance would be a centralization of the religions of the entire humankind, until it was highlighted that 'humankind' would be the goal and the alliance represent nothing but the tool to achieve these goals. ${ }^{47}$

There are two members at the local group who are standing on the grounds of religion of idealism and therefore somewhat distanced to the confessionals. One of them explained that he is missing your [Otto's] historical explanation for the whole business. He explained

Marburg; OA1784, by Adolf Allwohn/no title/no date/Rudolf Otto-Archive Religionskundliche Sammlung, Philipps-University Marburg.

46 "Für Ihren Willkommensgruss danke ich Ihnen im Namen der Ortsgruppe recht herzlich. Wir haben vor einigen Tagen eine Sitzung abgehalten und uns dabei über die Ziele und die Aufgaben des R.M.B ausgesprochen. Es sind dabei einige Wünsche für den Plan und die Richtung des R.M.B. laut geworden, die ich Ihnen mitteilen soll." See: OA1760, by Adolf Allwohn/no title/ 28.04.1921/Rudolf Otto-Archive Religionskundliche Sammlung, Philipps-University Marburg. Translated by the author.

47 "Sehr geehrter Herr Professor! [...] Man [die Ortsgruppe] vermisste von verschiedenen Seiten her eine nähere Begründung des Namens Religiöser Menschheitsbund. Man dachte sich zuerst die Sache so, dass der Bund eine Zusammenfassung der Religionen in der ganzen Menschheit bezwecke, bis dann darauf aufmerksam gemacht wurde, dass "Menschheit" wohl das zu erreichende Ziel sei, und dass der Bund der Religionen nur das Mittel zur Verwirklichung dieses Zieles darstelle." See: OA1789, by Adolf Allwohn/no title/no date/Rudolf Otto-Archive Religionskundliche Sammlung, Philipps-University Marburg. Translated by the author. 
that it would not be anything new you want to achieve. It would be the idea of the eternal right and the eternal peace, expressed earlier by Spinoza, Leibnitz and Kant. ${ }^{48}$

These quotations are interesting in various ways. First, they show that the local groups had influence over the positioning of the RMB and that the group members had the potential to, and the interest in, becoming actively involved in forming the RMB. Secondly, although the relationship between Otto and Allwohn remained formal, there was vivid exchange of ideas and concerns between the two.

Allwohn emphasized the role of the religious individual in creating unity among believers. However, he not only calls for this unity on the level of the religious individual but also on the level of the church, since he invites churches to get involved and work together for the same purpose. This underpins three major convictions Allwohn had in relation to the importance of the RMB's work: Firstly, he determined that there was work to do to reconcile the churches with each other ${ }^{49}$, secondly, he pointed at the importance of churches and religious communities to be proactive and take part in public life and thirdly, he asked religious institutions and religious individuals to make use of their political influence. ${ }^{50}$

In Allwohn's understanding of the RMB, all religious people and the consolidated churches should work together towards the greater goals of world peace, justice and moral purity. In his understanding categories like justice and morality are universal. Allwohn echoes Otto when he emphasizes that 'peace' by itself is not a significant ideal by itself and without the right framework. This frame-

48 "So gehören der Ortsgruppe zwei Männer an, die auf dem Boden der Religion des Idealismus stehen und so den Konfessionellen abhol sind. Einer von ihnen führte noch aus, dass er bei Ihnen die historische Begründung vermisse. Es sei doch nichts Neues, was Sie wollten. Es handle ich doch um die Ideen des ewigen Rechtes und des ewigen Friedens, die vorher von Spinoza, Leibnitz und Kant ausgebildet worden seien.” See: OA1760, by Adolf Allwohn/no title/28.04. 1921/Rudolf Otto-Archive Religionskundliche Sammlung, Philipps-University Marburg. Translated by the author.

49 "Die Arbeit an der Versöhnung der [...] Kirchen wird durch den R.M.B. nicht hinfällig.” See: OA1785, by Adolf Allwohn/Vom Religiösen Menschheitsbund von Adolf Allwohn /no date/Rudolf Otto-Archive Religionskundliche Sammlung, Philipps-University Marburg. Translated by the author.

50 "Wenn die Kirchen und Religionsgemeinschaften jetzt nicht diesen Schritt zur Gestaltung des öffentlichen Lebens tun, wird der Gang der Geschichte über sie hinwegschreiten, denn dann ist [...] ihre Bedeutungslosigkeit klar erkannt. Die Kräfte nämlich, die nicht mehr aktiv das Gesicht unserer Kultur mitbestimmen, sind belanglos geworden.” See: OA1785, by Adolf Allwohn/ Vom Religiösen Menschheitsbund/no date/Rudolf Otto-Archive Religionskundliche Sammlung, Philipps-University Marburg. Translated by the author. 
work is described as 'justice' or 'social justice' and is introduced as a central category for the RMB's work. ${ }^{51}$

In all these notes it still remains unclear what Allwohn meant exactly when he referred to these major concepts that made up the initial goals of the RMB, that is, 'justice', 'social justice' and 'moral purity'. These concepts are neither defined nor detailed. This lack of definition may be considered a major weakness for the RMB's theoretical foundation, considering the fundamental importance of these concepts for the RMB as such. Instead these categories are used as if they are universal, cross-culturally applicable and thus more or less independent of context.

When it comes to the question of who should reach the goals, Allwohn is convinced that it is the RMB's duty to unite all religious people, communities and churches in order to achieve their goals. ${ }^{52}$ Allwohn writes:

the consolidation within a nation is not enough, because almost all public and social damages are world-damages and therefore their disposal is only reachable by the collective action of the whole cultured-mankind. It is clear that the international morals is only reachable through the collaboration of all religions..$^{53}$

In accordance with Otto, Allwohn called for a national and international collaboration on the domestic, communal, national and international levels. He was

51 "Es handelt sich beim R.M.B. nicht nur um religiösen Pazifismus. "Friede um jeden Preis" ist überhaupt nicht das ausschlaggebende Ideal. Es muss vielmehr Recht und Gerechtigkeit um jeden Preis erkämpft werden. Wenn der religiöse Pazifismus das tut, dann steht er im Rahmen der Aufgaben eines R.M.B. denn dann liegt hier die Bemühung um ein Teilziel [...].” See: OA1785, by Adolf Allwohn/ Vom Religiösen Menschheitsbund/no date/Rudolf Otto-Archive Religionskundliche Sammlung, Philipps-University Marburg. Translated by the author.

52 "Die grossen Ideen der Gerechtigkeit und der moralischen Reinheit werden in der ganzen Welt vertreten. Es handelt sich jetzt nur darum, dass diese Prinzipien auch angewandt werden auf die Gestaltung des Öffentlichen und zwischenstaatlichen Lebens. Diese Aufgabe will der Religiöse Menschheitsbund, der Bund aller religiösen Menschen und aller Religionsgemeinschaften übernehmen.” See: OA1785, by Adolf Allwohn/ Vom Religiösen Menschheitsbund/no date/ Rudolf Otto-Archive Religionskundliche Sammlung, Philipps-University Marburg. Translated by the author.

53 "Aber der Zusammenschluss innerhalb eines Volkes genügt nicht, weil fast alle öffentlichen und sozialen Schäden Weltschäden sind und deshalb ihre Beseitigung nur durch ein gemeinsames Vorgehen der gesamten Kulturmenschheit zu erreichen ist. Ganz klar ist es ja, dass die zwischenstaatliche Moral nur durch ein Zusammenarbeiten aller Religionen wirksam beeinflusst werden kann.” See: OA1785, by Adolf Allwohn/ Vom Religiösen Menschheitsbund/no date/Rudolf Otto-Archive Religionskundliche Sammlung, Philipps-University Marburg. Translated by the author. 
convinced that morality emerges throughout all cultures and national borders, ${ }^{54}$ and is shared by all religious individuals and penetrates private lives, extends to the family life, community life and stretches finally to the state life..$^{55}$

In the question of who should participate, Allwohn was far more inclusive than Otto. While Otto felt that the RMB members should be religious and therefore united in their subjective feeling and experience of being religious, Allwohn fostered RMB memberships beyond the religious experience. He expressed that not only religious communities must be activated to join, but that anybody who is of good will must come together. ${ }^{56}$ His understanding of who should participate was an ambitious goal by itself- theoretically and practically. Aiming at including religious and non-religious members implied moving beyond an interreligious organization and towards a political movement. In these questions, Allwohn's vision reached beyond what Otto was imagining for the RMB.

On the question of how these goals- justice, moral purity, and world-peace, would be reached, Otto suggested two strategies: one was to create the already mentioned Weltgewissen and the second was to establish a parliament of religions. Allwohn follows up on Otto's notion of the Weltgewissen and emphasized its importance as shown in these two quotes:

All the genuine movements will not reach their goals as the public and the will of the communities and nations do not stand behind them. Therefore, in order to stop the world's misery, the will of the people has to be woken up and this will have to be put forefront to support the great moral ideas and justice and the community. Therefore, the building of a public consciousness which is against all injustice and anti-moral and has a lively interest in the good. ${ }^{57}$

54 "Das aus dem Religiösen kommende gute Handeln darf keine Grenzen und Beschränkungen kennen, sondern muss sich auf alles erstrecken.” See: OA1785, by Adolf Allwohn/ Vom Religiösen Menschheitsbund/no date/Rudolf Otto-Archive Religionskundliche Sammlung, Philipps-University Marburg. Translated by the author.

55 "Sittliche Aktivität. Privatleben, Familienleben. Leben [aus] der Gesellschaft heraus. Muss sich auch erstrecken bis ins Staatsleben und in das Leben der Menschheit [...]” See: OA1783, by Adolf Allwohn/no title/no date/Rudolf Otto-Archive Religionskundliche Sammlung, Philipps-University Marburg. Translated by the author.

56 "Und nicht nur die Religionsgemeinschaften und die Menschen, die in einem engeren Sinne religiös sind, sollen aufgerufen werden, sondern alle die, die guten Willen sind und die sich von grossen sittlichen Ideen bestimmen lassen. - Alle diese Menschen und Gruppen müssen jetzt aus ihrer Vereinzelung hervortreten. In fast allen Ländern sind mehrere Kirchen oder sogar mehrere Religionen nebeneinander vorhanden, so dass jede dieser Gruppen für sich allein machtlos ist.” See: OA1785, by Adolf Allwohn/ Vom Religiösen Menschheitsbund/no date/Rudolf Otto-Archive Religionskundliche Sammlung, Philipps-University Marburg. Translated by the author. 57 "Und so lange werden auch alle wirklich gutgemeinten Bewegungen das Ziel nicht erreichen, als nicht die öffentliche Meinung und der Wille der Gruppen und Völker hinter ihnen 
Therefore, there is the demand: Religions of all countries unite. This invocation will wake up the churches, the religious communities and the individual. Next all the representatives of those groups who hear the call will meet periodically in certain countries and world congresses to discuss the big questions of the public and international community. Such a parliament of religions will have great influence if the will of all the religious stand behind them, the will to justice and moral purity, the will of redevelopment of culture out of the spirit of the religion. When this will is awake in broad parts of the people, and then a true league of people will be possible, because just then the relationships and people as well as the races, classes [...] are able to be given an order in the spirit of justice. ${ }^{58}$

Allwohn perceived the Weltgewissen, first and foremost, as a means to oppose politics. People of all religions, religious people of all denominations and people without denomination should be activated and made aware of their political powers. These powers were supposed to be united beyond the borders of nations, to build a shared intellectual and moral basis, which would be discussed in local national groups and further specified in the international parliament of religions where representatives of all religions would come together and build a collective, an alliance to oppose political leaders if necessary. Allwohn was convinced that this social change started with the re/discovery of the religious sensibility as subjective experience, but he also considered religious principles to be a uniting factor to build a collective and foster political and social changes. The civil society as a whole would be strengthened and better prepared not only to overcome injustice more easily but also better prepared to prevent future injustice.

steht. Es muss also in erster Linie zur Behebung der Weltnot das Wollen der Menschen wachgerufen werden und dieses Wollen muss von neuem unter die grossen sittlichen Ideen der Gerechtigkeit und der Gemeinschaft gestellt werden. Es handelt sich deshalb einzig und allein um die Bildung eines öffentlichen Gewissens, das alle Ungerechtigkeit und Unsittlichkeit entschieden ablehnt und lebendiges Interesse an der Förderung alles Guten hat.” See: OA1785, by Adolf Allwohn/ Vom Religiösen Menschheitsbund/no date/Rudolf Otto-Archive Religionskundliche Sammlung, Philipps-University Marburg. Translated by the author.

58 "Deshalb gilt die Mahnung: Religiöse aller Länder vereinigt euch.” Dieses gemeinsame Aufrufen wird die Kirchen, die Religionsgemeinschaften und die Einzelnen erwachen lassen. Dann werden sich die berufenen Vertreter dieser Gruppen und Kreise zusammenfinden und in periodisch wiederkehrenden Ländern und Weltkongressen die grossen Fragen des öffentlichen und zwischenstaatlichen Lebens besprechen. Ein solches Religionspaarlament wird grossen Einfluss haben, wenn hinter ihm der Wille aller Religiösen steht, der Wille zu Gerechtigkeit und sittliche Reinheit, der Wille zur Neugestaltung der Kultur aus dem Geiste der Religion. Wenn dieser Wille in breiten Volksschichten geweckt ist, dann wird zum Beispiel auch erst ein wahrer Völkerbund, [...] denn dann werden erst die Beziehungen der Völker wie auch der Rassen, Klassen [...] im Sinne der Gerechtigkeit geordnet werden können.” See: OA1785, by Adolf Allwohn/ Vom Religiösen Menschheitsbund/no date/Rudolf Otto-Archive Religionskundliche Sammlung, Philipps-University Marburg. Translated by the author. 
Therefore, Allwohn's first and foremost goal was to find a collective and bring together those who want to participate in creating the Weltgewissen. ${ }^{59}$ This collective was envisaged to bring together the inherent powers of communities and the powers of religious individuals, in other words, the united political power of civil societies.

In regard to the second part of implementing the RMB, namely, to form a parliament of religions Allwohn was less outspoken. What is sure is that the RMB was not the only organization at the time that was working on implementing religious awakening and social movement. There were similar initiatives founded independently from the RMB. Allwohn explicitly wrote in his notes about the League of Religions in England, within which adherents of six world religions participated: Christians, Jews, Muslims, Hindus, Buddhists and Parsis.

The RMB reached out to these organizations willing to network and cooperate. ${ }^{60}$ The strategy of networking would have certainly been helpful to reach the goal of forming a parliament of religions in the future. However, the main focus for Allwohn was to reach out to Germans and to establish a broad network of local German groups. Allwohn, who himself led the local group Offenbach and supported the RMB's aim to activate religious people in the area, understood these group meetings to be a means to stimulate open discussions. It appears

59 "Welchen Weg wird der R.M.B zur Erreichung dieser Ziele beschreiten müssen? - Zunächst wird es sich um die Sammlung aller derer handeln, die erkannt haben, dass die religiösen Kräfte hinaustreten müssen ins Leben, um die Weltnot zu überwinden und um eine gute Neugestaltung zu erreichen. Diese Menschen werden zusammen mit dem Bund immer wieder ausrufen: "die Religion ist nicht tot, sie hat im Gegenteil gerade in unserer Zeit noch viel zu sagen. [...] Wenn sich die Menschen besinnen und den religiösen Grundsätzen die ihnen gebührende Föhrung [sic!] einräumen, dann werden alte Schäden bermietent bestigt und neu vermieden werden können. Aber ein gemeinsames Vorgehen ist unumgänglich notwendig.” See: OA1785, by Adolf Allwohn/ Vom Religiösen Menschheitsbund/no date/Rudolf Otto-Archive Religionskundliche Sammlung, Philipps-University Marburg. Translated by the author.

60 "Dass der Gedanke eines R.M.B. einem Bedürfnis der ganzen Welt entspricht, zeigen die begeisterten Zuschriften nicht nur aus Deutschland, sondern auch aus Schweden, Holland, Österreich, der Schweiz, Italien, England, Amerika, Indien und Japan. Und dass es sich auch nicht um ein Unternehmen handelt, das Deutsche in erster Linie zur Abwendung der besonderen Notlage ihres Landes unternehmen haben, geht daraus hervor, dass ganz unabhängig vom R.M.B. ähnliche Bestrebungen [...] der vor kurzem in England gegründeten "League of Religions", [...] an dem die Vertreter von sechs grossen Religionen: Christen, Juden, Mohammedaner, Hindus, Buddhisten und Parsis beteiligt sind. Die deutsche Bewegung hat mit diesen Bewegungen der anderen Länder schon eine enge Fühlung gewonnen, sodass die Verwirklichung der gemeinsamen grossen Aufgabe nur noch eine Frage der Zeit sein kann.” See: OA1785, by Adolf Allwohn/ Vom Religiösen Menschheitsbund/no date/Rudolf Otto-Archive Religionskundliche Sammlung, Philipps-University Marburg. Translated by the author. 
that these discussions were an important tool to reach consent on two recurring questions: what does the RMB stand for as well as who should be able to join. Issues that remained unresolved.

\section{The RMB Conference and Financial Challenges}

One of the most severe everyday concerns was the constant lack of sufficient funding: "Still there are funds needed, for now, 500 Mark, for defrayal of office and travel expenses. We are turning trusting to you with the request to help fast."61

Reading these lines points to the serious problem Allwohn faced within the RMB. The organization was chronically suffering from a substantial lack of funding. The only regular funding came from the membership contributions, which hardly covered the basic costs. However, not every local group was suffering financially in the same way or to a similar extent.

It is quite intriguing that, despite the tight financial situation, the RMB conference took place in Eisenach in 1922, organized to follow in junction to another international conference. Thus, the RMB conference was relatively well attended and considered an overall success. ${ }^{62}$ Despite this success, however, the precarious financial situation certainly became a fundamental reason behind the unsustainability of the RMB. ${ }^{63}$

\section{Allwohn's Turn Away: Times of Radicalization}

Shortly after the conference, the RMB started slowly to cut down on activities and then closed down quietly. One may argue that Allwohn's loss of interest in his position in the RMB and the tacit death of the RMB are no coincidences. The occurrence of both should, rather, be seen as symptoms of a change of the Zeitgeist in Germany. As much as the aftermath of the WWI created time and space for organizations like the RMB to promote conversations on peace and justice, the

61 "Noch aber fehlen uns die nötigen Geldmittel es wird sich zunächst um etwa 500M handeln, zur Bestreitung der Büro- und Reise- und Druckkosten. Deshalb wenden wir uns vertrauensvoll an Sie mit der Bitte um schnelle Hilfe.” See: OA1765, by Adolf Allwohn/no title/no date/Rudolf Otto-Archive Religionskundliche Sammlung, Philipps-University Marburg. Translated by the author.

62 See: Obergethmann, "Rudolf Ottos 'Religiöser Menschheitsbund': Ein Kapitel,” 81.

63 See: Obergethmann, "Rudolf Ottos 'Religiöser Menschheitsbund': Ein Kapitel,” 80 -81. 
1920s was a time of insidious political polarization and radicalization, which left very little space for these same organizations to continue their work. This change of the Zeitgeist and Allwohn's growing sympathy towards the National Socialist ideology ceased his endeavours to implement Otto's ideas and visions in regard to the RMB.

During the first year after its establishment, the RMB thrived and looked as though it would be a promising project. However, Allwohn's engagement, as active and promising as it might have been during the first two years, lost his drive rapidly in the third year. The last date found on Allwohn's documents is May 1923, just two years after he was appointed general secretary. ${ }^{64}$ The lack of any document dated beyond this one indicates that he may have stopped his work with the RMB around this time. Due to the lack of sources, however, the exact date and reasons for this step remain inexplicable.

Looking at his subsequent development as an academic, it is clearly evident that later on in his career he had begun to have a great interest in the growing national-socialist ideas of the time. In 1934 he published an article titled Radical Revolution in which he praises das Dritte Reich as the needed turnaround, not only encompassing politics and economy, but also science, art, ideology and private life. ${ }^{65}$ He became part of the Deutsche Christen movement, which aimed to unite all Christians in Germany, a movement also supported by Hitler's regime.

After publishing Radical Revolution, however, Allwohn was also known to be in contact with a new protestant movement named the Bekennende Kirche, known to be against the coordination of all Christians in Germany. A few years later Allwohn's academic career was interrupted. He lost his chair at the University of Giessen in 1940, to which he was appointed for eight years earlier in $1932 .{ }^{66}$ After the end of WWII and due to the intervention of the Americans at the University of Giessen, Allwohn regained his professorship, but the university closed in 1950. Allwohn, therefore, had to change universities, succeeding in 1948. He ended his academic career in 1964 as a lecturer in the Philosophy Department at the University of Frankfurt and continued to work as pastor and psychotherapist. ${ }^{67}$ Allwohn wrote in a letter in 1952:

64 See: OA1808, by Adolf Allwohn/no title/13.05.1923/Rudolf Otto-Archive Religionskundliche Sammlung, Philipps-University Marburg.

65 Adolf Allwohn, "Evangelischer Glaube im Dritten Reich, Kirche im Angriff: Brennende Fragen der Gegenwart,” Volksmissionarische Schriften 1 (1934): 7-8.

66 See: Choi, Religion als 'Weltgewissen', 60.

67 Heinz Röhr, “Adolf Allwohn: Vorläufer der Seelsorgertheorie,” in. Evangelische Theologie und Religionsphilosophie an der Universität Frankfurt am Main: 1945 bis 1989, eds. Dieter Stoodt, Karl- 
My lectureship gives me great pleasure. [...] Only, it is painful to me that I could not find time to publish anything so far. [...] As pastor I am for one year of use as hospital pastor. In addition, I am giving some psychotherapeutic treatments and instructive analyzes. - The faculties are not yet ready to recognize the meaning of in-depth psychology and to request a specialist in this area. ${ }^{68}$

Despite the promising and ambitious beginning of this man's career, it came to a relatively quiet end.

\section{Conclusion}

The Religiöse Menscheitsbund / Religious Union of Humankind (the RMB) is an early example of an interreligious dialogue organization. Starting as a theoretical idea developed during WWI, Rudolf Otto founded the RMB in 1921 as an organization aimed at creating a Weltgewissen shared by world religions. This essay examined its premature failure, analyzing the impact of Adolf Allwohn, the RMB's first and only General Secretary in relation to its failure of implementation. The failure of the RMB may be inextricably linked to the tension between the organization's theoretical ideal and the practical implementation of the RMB.

The RMB emerged out of historical times, in the aftermath of the WW I crisis and the Spanish flu pandemic, but also ended at a time of growing socio-political developments in Germany that foreshadowed the impending second world war. The formation of the RMB, and especially its failure, shows the situation of crisis in which Christianity in Europe fell after the end of WWI. In the aftermath of this cruelty and horror, several Christian organizations emerged on the scene, emphasizing the importance of peace, interreligious and intercultural dialogue, as well as the importance of social justice. These organizations' ideas and principals seemed rather timely, including Otto's RMB. Otto, the well-known theorist, had the vision that all world religions should cooperate with each other in aspiration for mutual respect and equality. He understood the RMB's role as a

Gerhard Steck, Wolfgang Philipp, Adolf Allwohn, Hans-Werner Bartsch, Walter Dignath and Hans-P. Schmidt (Frankfurt am Main.: Peter Lang, 1991): 155-163.

68 "Meine Vorlesungstätigkeit macht mir viel Freude. [...] Es schmerzt mich nur, dass ich bis jetzt keine Zeit für Veröffentlichungen gefunden habe. [...] Als Pfarrer bin ich seit einem Jahr in der Krankenhausseelsorge eingesetzt. Daneben führe ich einige psychotherapeutische Behandlungen und Lehranalysen durch. - Die Fakultäten sind leider noch nicht so weit, dass sie die Bedeutung der Tiefenpsychologie erkannt hätten und dass sie einen Fachmann auf diesem Gebiet anforderten.” See: OA1754, by Adolf Allwohn/no title/14.01.1952/Rudolf Otto-Archive Religionskundliche Sammlung, Philipps-University Marburg. Translated by the author. 
platform for negotiating social justice and peace, in addition to and in opposition to political powers.

Although Allwohn's remaining RMB papers and documents are rather fragmented, they still allow precious insights into the everyday concerns and challenges of the young and ambitious general secretary. Allwohn shared Otto's vision and ambitions to implement an international dialogue platform and besides being a representative figure, worked on practical matters like founding local groups, activating group members and collecting membership payments, throughout Germany.

During Allwohn's time as the RMB's general secretary, he encouraged discussions in the local group meetings, where the RMB principals were negotiated. By interpreting and negotiating Otto's ideas he prepared them for implementation. However, concrete guidelines may have been needed to support a lasting implementation and a definition of the core concepts of the alliance, such as what is meant by "social justice", or "all" religious people. Such concepts are not defined in detail by Otto or Allwohn.

Additionally, two crucial problems hindered the development of the RMB: the lack of regular funding reflected in the circumstances the only conference was held and, relatively speaking, modest interest in the RMB within Germany. For example, not all the German churches contacted were interested in participating in the RMB's vision and therefore blocked its growth. These are considered to be two main factors contributing to its eventual failure.

In 1923, only two years after starting his appointment, Allwohn drifted away from the alliance. The reasons for Allwohn's departure from his position as the general secretary of the RMB and the RMB's silent fading and final failure may include a shift of the Zeitgeist, embodied in the political radicalization of Allwohn, who seemed to have been somewhat sympathetic towards fascist idealism. Rudolf Otto on the opposite resisted these tendencies but, unfortunately, suffered from illness and did not have the constitution to continue the RMB. Several attempts to revive the RMB after the second world war failed. The case of the RMB shows that even if a vision is seemingly timely it cannot be implemented without a very specific organizational profile, financial support, network and the right political environment.

Although the RMB was a seemingly timely endeavour and initially able to attract worldwide interest due to Otto's international social network, the organization reached the climax of its activities and achievements already one year after its inception, when it held its only international conference in 1922. Being left without lasting national or international support, the RMB became gradually inactive in the following years, until it finally stopped its activities altogether at the end of the decade. According to Choi the reasons for its failure are 
diverse and ambiguous. She also points at Otto's RMB revival attempts in the early 1930s, as well as those of other RMB supporters immediately after WWII and then again in the 1950s. However, these attempts never made a lasting breakthrough. ${ }^{69}$

A century later the RMB might have still struggled, although "most world religions have some form of worldwide representative organization and gathering opportunity." ${ }^{\text {"70 }}$ Most of these organizations dialogue foremost communalities, differences and limitations within- and between their communities. The RMB, however, was calling for a very different approach, a focus that goes beyond religious boundaries, but making religion the instrument and key to mobilize people to discuss socio-political themes. In this respect Otto's RMB was- and probably still is one step ahead of past and current interreligious and intrareligious efforts.

\section{Acknowledgements}

I would like to express my gratitude to Martin Kraatz - the former Director of the Religionskundliche Sammlung Marburg (1968-1998) and Otto expert. I had the opportunity and privilege to access Kraatz's private collection of Otto-correspondence transcripts. These files are the product of more than five decades of his and his late wife, Margot Kraatz's, work. Furthermore, I would like to thank Jörg Lauster, Peter Schütz, Ulrich Rosenhagen and Karl Pinggera, Bernd Reifenberg and Karolina Degendorf.

\section{Bibliography}

\subsection{Primary Sources}

OA1282, by Rudolf Otto/Weltgewissen und die Wege dazu/no date/Rudolf Otto-Archive Religionskundliche Sammlung, Philipps-University Marburg.

OA1758, by Adolf Allwohn/no title/no date/Rudolf Otto-Archive Religionskundliche Sammlung, Philipps-University Marburg.

OA1759, by Adolf Allwohn/no title/no date/Rudolf Otto-Archive Religionskundliche Sammlung, Philipps-University Marburg.

69 See: Choi, Religion als 'Weltgewissen', 3. This failure notwithstanding, one can argue that RMB's ideas and principles are again detected in today's world, e.g. reflected in the work of Hans Küngs' Weltethos foundation (1995).

70 See: Cheetham, Pratt, and Thomas, Understanding interreligious Relations, 3. 
OA1765, by Adolf Allwohn/no title/no date/Rudolf Otto-Archive Religionskundliche Sammlung, Philipps-University Marburg.

OA1768, by Adolf Allwohn/no title/no date/Rudolf Otto-Archive Religionskundliche Sammlung, Philipps-University Marburg.

OA1783, by Adolf Allwohn/no title/no date/Rudolf Otto-Archive Religionskundliche Sammlung, Philipps-University Marburg.

OA1784, by Adolf Allwohn/no title/no date/Rudolf Otto-Archive Religionskundliche Sammlung, Philipps-University Marburg.

OA1785, by Adolf Allwohn/ Vom Religiösen Menschheitsbund/no date/Rudolf Otto-Archive Religionskundliche Sammlung, Philipps -University Marburg.

OA1789, by Adolf Allwohn/no title/no date/Rudolf Otto-Archive Religionskundliche Sammlung, Philipps-University Marburg.

OA1792, by Adolf Allwohn/no title/no date/Rudolf Otto-Archive Religionskundliche Sammlung, Philipps-University Marburg.

OA1795, by Adolf Allwohn/no title/no date/Rudolf Otto-Archive Religionskundliche Sammlung, Philipps-University Marburg.

OA1760, by Adolf Allwohn/no title/28.04.1921/Rudolf Otto-Archive Religionskundliche Sammlung, Philipps-University Marburg.

OA1808, by Adolf Allwohn/no title/13.05.1923/Rudolf Otto-Archive Religionskundliche Sammlung, Philipps-University Marburg.

OA1754, by Adolf Allwohn/no title/14. 01.1952/Rudolf Otto-Archive Religionskundliche Sammlung, Philipps-University Marburg.

\subsection{Secondary Sources}

Allwohn, Adolf. "Evangelischer Glaube im Dritten Reich, Kirche im Angriff: Brennende Fragen der Gegenwart." Volksmissionarische Schriften 1 (1934): 13-24.

Axel, Brian Keith, ed. From the Margins: Historical Anthropology and its Futures.

Durham/London: Duke University Press, 2002.

Brundage, Anthony. Going to the Sources: A Guide to Historical Research and Writing. Illinois: Harlan Davidson, 2002.

Catherine, Cornille, ed. The Wiley-Blackwell Companion to Inter-Religious Dialogue. John Wiley \& Sons: Hoboken and West Sussex, 2013.

Cheetham, David, Douglas Pratt, David Thomas, ed. Understanding interreligious Relations. Oxford: Oxford University Press, 2013.

Choi, Jeong Hwa. Religion als “Weltgewissen": Rudolf Ottos Religiöser Menschheitsbund und das Zusammenspiel von Religionsforschung und Religionsbegegnung nach dem Ersten Weltkrieg. Zürich/Berlin: LIT, 2013.

Coffey, Amanda. "Analysing Documents." In The SAGE handbook of Qualitative Data Analysis, edited by Uwe Flick, 367-79. London: SAGE, 2014.

Glockzin-Bever, Sigrid and Martin Kraatz, eds. Am Kreuz eine Frau: Anfänge, Abhängigkeiten, Aktualisierungen. Münster: LIT Verlag, 2003.

Howe, Cymene and Stephanie Takaragawa. Failure: "Theorizing the Contemporary." Fieldsights (July 27, 2017): http://culanth.org/fieldsights/failure (accessed: 24.5.2020). 
Lauster, Jörg, Peter Schütz, Roderich Barth and Christian Danz, eds. Rudolf Otto: Theologie-Religionsphilosophie-Religionsgeschichte. Berlin/Boston: De Gruyter, 2014.

Moyaert, Marianne. “Interreligious Dialogue.” In Understanding Interreligious Relations, edited by David Cheetham, Douglas Pratt and David Thomas, 193-217. Oxford: Oxford University Press, 2013.

Obergethmann, Frank. "Rudolf Ottos "Religiöser Menschheitsbund: ein Kapitel interreligiöser Begegnung zwischen den Weltkriegen.” Zeitschrift für Religionswissenschaft 6 (1998): $79-107$.

Otto, Rudolf. "Das Gefühl der Verantwortlichkeit.” Zeitschrift für Religionspsychologie 4 (1931): 143-174.

Otto, Rudolf. “Religiöser Menschheitsbund neben politischem Völkerbund.” Die Christliche Welt 34 (1920): 133-135.

Otto, Rudolf. “Vom Religiösen Menschheitsbunde.” Die Christliche Welt 34 (1920): 477-78.

Otto, Rudolf. Autobiographical and Social Essays, translated \& edited by Gregory D. Alles. Berlin /New York: Mouton de Gruyter, 1996.

Otto, Rudolf. Das Heilige: Über das Irrationale in der Idee des Göttlichen und sein Verhältnis zum Rationalen. Breslau: Trewendt und Granier, 1923.

Röhr, Heinz. "Adolf Allwohn: Vorlaufer der Seelsorgertheorie." In Evangelische Theologie und Religionsphilosophie an der Universität Frankfurt am Main: 1945 bis 1989, edited by Dieter Stoodt, Karl-Gerhard Steck, Wolfgang Philipp, Adolf Allwohn, Hans-Werner Bartsch, Walter Dignath and Hans-P. Schmidt, 155-163. Frankfurt am Main: Peter Lang, 1991.

Schinzer, Reinhard. “Rudolf Otto: Entwurf einer Biographie.” In Rudolf Otto’s Bedeutung für die Religionswissenschaft und die Theologie heute: zur Hundertjahrfeier seines Geburtstags, edited by Ernst Benz, 1-29. Leiden: Brill, 1971.

\section{Annex}

\subsection{Annex 1: 0A1758}

Adolf Allwohn/no title/no date/Rudolf Otto-Archive Religionskundliche Sammlung, Philipps-University Marburg

Die mir zugedachte Tätigkeit sich durchaus nicht im organisatorischer Arbeit erschöpfen sollte sondern hauptsächlich in einem religiösen Aufrufern bestehen sollte, fühlte ich mich von Gott zu diesem Werk berufen, zumal. Und-Ich stehe so unter dem starken Eindruck, dass Gott mir hier einen Weg gezeigt hat, auf dem ich meinem innersten Beruf nachkommen kann. Ich danke Ihnen deshalb für Ihr Anerbieten von ganzem Herzen und hoffe, dass Gott nur die Kraft geben wird für die grossen Aufgabe sie zu wirken, wie sie es verdient. - Ich war schon lange auf der Suche nach einer Tätigkeit, die mich über das Amt eines Angestellten der Kirche hinausführen könnte. Zwar liegt mir das seelsorgerische wirken, die Arbeit der religiösen Vertiefung und der Andachtsleitung durchaus, aber das Herzkon- 
storium (?) hatte mir das Versprechen abgenommen, in meiner amtlichen Tätigkeit von meinem Besten, zu schweigen und nur das zu bringen, was den Leuten aus dem Herzen gesprochen sein. (So hat man jetzt auch einen anderen hessischen Pfarrer gesagt: Wir sind überzeugt, dass Sie nur Christus verkündigen, aber haben nicht nur diese Aufgabe, sondern wir sind auch Kirche und da müssen Sie auf die (...??) und ich hoffe für mein seelsorgerisches Wirken auch nach Am dem Aufgaben meines Amtes immer einen kleinen Kreis zu haben, den ich hier dienen kann. - Um Missverständnisse zu vermeiden, möchte ich ausdrücklich betonen, dass ich durchaus das Gute an der Kirche und auch die Möglichkeit manch schönen Wirkens sehe, dass ich mich aber entschieden dagegen wenden muss, dass jede religiöse Weiterführung z.B. zu einer Ablehnung des Völkerhasses verboten wird. - Wenn ich so smeiner eigentlichen Aufgabe nicht im Rahmen des Pfarrberufes nachgehen kann, so werden Sie es verstehen, dass ich möglichst bald mein Amt aufgeben möchte und in meiner Sekretärtätigkeit auf die Ermöglichung dieses Aufgabens hinarbeiten werde.

\subsection{Annex 2: OA1760}

Adolf Allwohn/no title/28.04.1921/Rudolf Otto-Archive Religionskundliche Sammlung, Philipps-University Marburg

Offenbach 28. April 1921

Waldstrasse $124 \mathrm{pt}$

\section{Sehr geehrter Herr Professor!}

Für Ihren Willkommensgruß danke ich Ihnen im Namen der Ortsgruppe recht herzlich. - Wir haben vor einigen Tagen eine Sitzung abgehalten und uns dabei über die Ziele und die Aufgaben des R.M.B ausgesprochen. Es sind dabei einige Wünsche für den Plan und die Richtung des R.M.B. laut geworden, die ich Ihnen mitteilen soll.

Man vermisste von verschiedenen Seiten her eine nähere Begründung des Namens Religiöser Menschheitsbund. Man dachte sich zuerst die Sache so, dass der Bund eine Zusammenfassung der Religionen in der ganzen Menschheit bezwecke, bis dann darauf aufmerksam gemacht wurde, dass "Menschheit" wohl das zu erreichende Ziel sei, und dass der Bund der Religionen nur das Mittel zur Verwirklichung dieses Zweckes darstelle. Man könnte das wohl im Plan der Bewegung noch näher zum Ausdruck bringen. - Man beanstandete ferner, dass nur die Konfessionen zusammengefasst werden sollen und nicht alle religiösen Menschen überhaupt, denn es sei doch heutzutage weiterhin so, dass 
wir den Zusammenhang mit einer Konfession aufgegeben hätten, ohne aufgegeben zu haben, für sich religiös zu sein, und ohne die Bereitschaft zur Mithilfe der Überwindung der Menschheitsnöte aufgegeben zu haben. - So gehören der Ortsgruppe zwei Männer an, die auf dem Boden der Religion des Idealismus stehen und so den Konfessionellen abhold sind. Einer von ihnen führte noch aus, dass er bei Ihnen die historische Begründung vermisse. Es sei doch nichts Neüs, was Sie wollten. Es handle sich doch um die Ideen des ewigen Rechtes und des ewigen Friedens, die vorher von Spinoza, Leibnitz und Kant ausgebildet worden seien. Wenn die Sache des RMB darauf aufgebaut würde, dann hätte sie auch grössere Wirkungsmöglichkeiten besonders im Ausland, das doch immer mehr die Philosophie Kants verehre. - Ich glaube nun zwar nicht, dass Sie diese einseitige Festlegung auf die religiösen Ideen Kants wählen werden, aber ich wollte Ihnen doch die geäusserten Bedenken mitteilen, damit Sie einen Überblick gewinnen können. - Ausserdem gehört der Ortsgruppe der hiesige konfessionslose Führer der Mehrheitssozialisten an, der von einer Diesseitsreligion der Verbundenheit mit allen Menschen, mit allen Dingen und mit dem All ausgeht. Auch er bittet um einen Platz im RMB - Er ist weiterhin der Wunsch geäussert worden, er möchte zu den Aufgaben des RMB doch auch diejenigen hinzugenommen worden, die mehr auf die einzelne Stadt oder auf das einzelne Volk beschränkt bleiben. Es wäre das die ganze Aufgabe der mit gemeinsamen Kräften in Angriff zu nehmenden Versittlichung des öffentlichen Lebens. Ich wäre Ihnen sehr dankbar, wenn ich hier über Ihre Absichten Näheres erfahren könnte.

Wir haben in unserer letzten Sitzung beschlossen, im Herbst gemeinschaftlich an die Öffentlichkeit zu treten mit einem Vortragsabend über "Völkergemeinschaft und Religion”. Die Vertreter der einzelnen Gruppen sollen nacheinander über dasselbe Thema von ihrer religiösen Überzeugung aus reden. Vorher soll innerhalb der einzelnen Konfessionen für den RMB geworben werden. - In der hiesigen evangelischen Gemeinde ist noch kein besonderes Interesse für die Sache vorhanden, weshalb ein größerer Vortrag wohl angebracht scheint. Dürfte ich Sie da vielleicht bitten, uns diesen Vortrag zu halten? Für eine zusagende Antwort wären wir Ihnen sehr dankbar.

Die Kasse der Ortsgruppe enthält etwa $110 \mathrm{M}$. Wieviel soll ich davon an Sie abschicken?

Ich möchte Ihnen bei dieser Gelegenheit herzlich danken für all das, was mit Ihrem Buche "Das Heilige" gegeben hat.

Ihr sehr ergebener

Adolf Allwohn

Pfarrassistent 


\subsection{Annex 3: OA1785}

Adolf Allwohn/ Vom Religiösen Menschheitsbund/no date/Rudolf Otto-Archive Religionskundliche Sammlung, Philipps-University Marburg

Vom Religiösen Menschheitsbund

von Adolf Allwohn

(1) Der Gedanke eines Religiösen Menschheitsbundes (R.M.B) ist von dem protestantischen Professor der Theologie an der Universität Marburg (Deutschland) D.Dr. Rudolf Otto ausgegangen, der durch sein Buch "Das Heilige" weit über Deutschlands Grenzen hinaus berühmt geworden ist. Dieses Buch hatte schon überzeugend dargelegt, dass alle Religionen trotz ihrer grossen Verschiedenheiten doch viele Ähnlichkeiten in ihrem Erleben des Heiligen haben. Jetzt vertritt Professor Otto auch den Gedanken, dass die grossen Weltreligionen in ihren sittlichen Forderungen weitgehend übereinstimmen. Diese Einsicht hat ihn dazu geführt, alle Religionen aufzurufen zu einem gemeinsamen Vorgehen in der Erneürung der Kultur. Die grossen Ideen der Gerechtigkeit und der moralischen Reinheit werden in der ganzen Welt vertreten. Es handelt sich jetzt nur darum, dass diese Prinzipien auch angewandt werden auf die Gestaltung des Öffentlichen und zwischenstaatlichen Lebens. Diese Aufgabe will der Religiöse Menschheitsbund, der Bund aller religiösen Menschen und aller Religionsgemeinschaften übernehmen.

Dass der Gedanke eines R.M.B. einem Bedürfnis der ganzen Welt entspricht, zeigen die begeisterten Zuschriften nicht nur aus Deutschland, sondern auch aus Schweden, Holland, Österreich, der Schweiz, Italien, England, Amerika, Indien und Japan. Und dass es sich auch nicht um ein Unternehmen handelt, das Deutsche in erster Linie zur Abwendung der besonderen Notlage ihres Landes unternehmen haben, geht daraus hervor, dass ganz unabhängig vom R.M.B. ähnliche Bestrebungen ausgehen von dem protestantischen Erzbischof von Schweden, N. Söderblom in Upsala, und von der vor kurzem in England gegründeten "League of Religions”, des “Bundes der Religionen”, an dem die Vertreter von sechs grossen Religionen: Christen, Juden, Mohammedaner, Hindus, Buddhisten und Parsis beteiligt sind. Die deutsche Bewegung hat mit diesen Bewegungen der anderen Länder schon eine enge Fühlung gewonnen, sodass die Verwirklichung der gemeinsamen grossen Aufgabe nur noch eine Frage der Zeit sein kann. Von welchen Erwägungen geht der R.M.B. aus? - Er hält in unserer Zeit nichts für so wichtig als die Rettung der Welt aus der gemeinsamen ungeheuren Not. Er denkt bei dieser Weltnot nicht nur an die wirtschaftlichen Schwierigkeiten, die in allen Ländern auf der Seite in Teürung, in Arbeitslosigkeit und in sozialem 
Elend und auf der anderen Seite in Wucher, in Übervorteilung und in einem riesigen Anschwellen einzelner Vermögen bestehen. Er denkt auch nicht nur an die politischen Schwierigkeiten, die in den wechselseitigen Beziehungen der Volksgruppen in einem Staat wie auch der Staaten und Völker untereinander vorhanden sind. Sondern er denkt vor allem an die Weltnot, in die die öffentliche Moral hineingeraten ist, er denkt an Unsitte und Unzucht, an Ausschweifung und Gewinnsucht, an Ungerechtigkeit und Ungeistlichkeit. Ergeht dabei auch von der Erkenntnis aus, dass alle einzelnen Schäden letzten Endes aus nichts anderes als auf die Erkrankung des Ethos zurückgehen und dass der Egoismus in seinen verschiedensten Formen die gemeinsame Not verursacht hat. - Es sind schon mancherlei Bewegungen vorhanden und es werden mancherlei Anstrengungen gemacht, um die Ichsucht der Gruppen und Völker $\mathrm{zu}$ überwinden und $\mathrm{zu}$ einer gemeinsamen Bewältigung aller Schwierigkeiten zu gelangen. Diese Anstrengungen müssen aber so lange erfolglos bleiben, als sie von Menschen ausgehen, die selbst an Sonderinteressen gebunden sind und so an die Stelle des bestehenden Egoismus nur einen neün setzen. Und so lange werden auch alle wirklich gutgemeinten Bewegungen das Ziel nicht erreichen, als nicht die öffentliche Meinung und der Wille der Gruppen und Völker hinter ihnen steht. Es muss also in erster Linie zur Behebung der Weltnot das Wollen der Menschen wachgerufen werden und dieses Wollen muss von neüm unter die grossen sittlichen Ideen der Gerechtigkeit und der Gemeinschaft gestellt werden. Es handelt sich deshalb einzig und allein um die Bildung eines öffentlichen Gewissens, das alle Ungerechtigkeit und Unsittlichkeit entschieden ablehnt und lebendiges Interesse an der Förderung alles Guten hat. Wer ist aber mehr berufen, diese Weckung des Gewissens in den Völkern und in ihrer Öffentlichkeit betreiben, als die Gemeinschaften und Organisationen, denen vornehmlich die Gewissensbildung und die Willensbildung in grossen sittlichen Fragen obliegt nämlich die Kirchen, die religiösen Gruppen und die mannigfachen Gemeinschaften zur Pflege sittlicher Kultur?

Welche Aufgaben erwachsen dem R.M.B. aus diesen Erwägungen? Das Erste muss sein, dass alle religiösen Menschen mobil gemacht werden und dass die Religionsgemeinschaften aufgerufen werden, auch die Gestaltung des öffentlichen Lebens der sozialen Verhältnisse und des Wechselverkehrs der Völker in Angriff zu nehmen. Gewiss ist die Pflege des religiösen Lebens der Einzelseele und die Pflege der gemeinschaftlichen Andacht die vornehmste Aufgabe jeder Religion, und gewiss darf es sich nicht darum handeln, dass dieses Hauptbetätigungsgebiet irgendwie verkürzt werde, Aber die Religion kann unmöglich bei den Förderungen der Privatmoral stehen bleiben, sondern sie muss ihre religiösen und sittlichen Massstäbe auch an das öffentliche und zwischenstaatliche Leben anlegen und muss auch dieses aus dem Geiste der Frömmigkeit und 
nach den Forderungen des religiösen Sittengesetzes zu gestalten versuchen. Das aus dem Religiösen kommende gute Handeln darf keine Grenzen und Beschränkungen kennen, sondern muss sich auf alles erstrecken und muss mit seinen starken Forderungen alle Gebiete ergreifen. - Wenn die Kirchen und Religionsgemeinschaften jetzt nicht diesen Schritt zur Gestaltung des öffentlichen Lebens tun, wird der Gang der Geschichte über sie hinwegschreiten, denn dann ist in den kulturtragenden Kreisen ihre Bedeutungslosigkeit klar erkannt. Die Kräfte nämlich, die nicht mehr aktiv das Gesicht unserer Kultur mitbestimmen, sind belanglos geworden. - Und nicht nur die Religionsgemeinschaften und die Menschen, die ein einem engeren Sinne religiös sind, sollen aufgerufen werden, sondern alle die, die guten Willen sind und die sich von grossen sittlichen Ideen bestimmen lassen. - Alle diese Menschen und Gruppen müssen jetzt aus ihrer Vereinzelung hervortreten. In fast allen Ländern sind mehrere Kirchen oder sogar mehrere Religionen nebeneinander vorhanden, so dass jede dieser Gruppen für sich allein machtlos ist. Hier muss also der Weg eines brüderlichen Zusammenwirkens beschritten werden, wie er zum Beispiel schon bei der "Trockenlegung” Amerikas, dieser von sittlichem ernst getragenen Beseitigung einer Quelle von Unzucht, Verwahrlosung, Laster und Gebrechen begangen worden ist, denn hierbei haben die verschiedensten konfessionellen und religiösen Gruppen entscheidend mitgearbeitet. Aber der Zusammenschluss innerhalb eines Volkes genügt nicht, weil fast alle öffentlichen und sozialen Schäden Weltschäden sind und deshalb ihre Beseitigung nur durch ein gemeinsames Vorgehen der gesamten Kulturmenschheit zu erreichen ist. Ganz klar ist es ja, dass die zwischenstaatliche Moral nur durch ein Zusammenarbeiten aller Religionen wirksam beeinflusst werden kann. Aber auch an der Lösung der Arbeiter-, Frauen- und Rassenfragen sind alle Völker interessiert und nur eine überstaatliche Regelung kann wirklichen Erfolg haben, allerdings erst dann, wenn die Neugestaltung dieser Verhältnisse von der öffentlichen Meinung der Welt als sittliche Notwendigkeit empfunden wird, wozu es einer Schärfung des Gewissens durch die Religionen bedarf. Auch die Beseitigung des Alkoholismus wird erst dann wirksam in einem Lande durchzuführen sein, wenn aus den anderen Ländern nicht immer wieder Versuche zur Durchbrechung des Verbots unternommen werden. - So muss als der Weg eines Weltbundes beschritten werden, der die Aufgabe hat, alle Religionsgemeinschaften und alle religiösen Menschen immer wieder zur Bildung eines öffentlichen Weltgewissens aufzurufen, eines Gewissens, das weiss, was sittlich gut ist und was die Gerechtigkeit erfordert und das so immer wieder das Volks und Völkerleben nach den Grundsätzen der Moral zu gestalten versucht.

Welchen Weg wird der R.M.B zur Erreichung dieser Ziele beschreiten müssen? - Zunächst wird es sich um die Sammlung aller derer handeln, die er- 
kannt haben, dass die religiösen Kräfte hinaustreten müssen ins Leben, um die Weltnot $\mathrm{zu}$ überwinden und um eine gute Neugestaltung $\mathrm{zu}$ erreichen. Diese Menschen werden zusammen mit dem Bund immer wieder ausrufen: "die Religion ist nicht tot, sie hat im Gegenteil gerade in unserer Zeit noch viel zu sagen. Sie will das gemeinsame Leben in Volk und Menschheit erneürn. Wenn sich die Menschen besinnen und den religiösen Grundsätzen die ihnen gebührende Führung einraumen, dann werden alte Schäden beseitigt und neü vermieden werden können. Aber ein gemeinsames Vorgehen ist unumgänglich notwendig. Deshalb gilt die Mahnung: Religiöse aller Länder vereinigt euch.” Dieses gemeinsame Aufrufen wird die Kirchen, die Religionsgemeinschaften und die Einzelnen erwachen lassen. Dann werden sich die berufenen Vertreter dieser Gruppen und Kreise zusammenfinden und in periodisch wiederkehrenden Ländern und Weltkongressen die grossen Fragen des öffentlichen und zwischenstaatlichen Lebens besprechen. Ein solches Religionsparlament wird grossen Einfluss haben, wenn hinter ihm der Wille aller Religiösen steht, der Wille zu Gerechtigkeit und sittliche Reinheit, der Wille zur Neugestaltung der Kultur aus dem Geiste der Religion. Wenn dieser Wille in breiten Volksschichten geweckt ist, dann wird zum Beispiel auch erst ein wahrer Völkerbund, der wirklich vom Geiste sittlichen Ernstes getragen ist, möglich sein, denn dann werden erst die Beziehungen der Völker wie auch der Rassen, Klassen und Schichten im Sinne der Gerechtigkeit geordnet werden können.

(4) Zum Schluss werden sollen noch einige etwa auftauchende Fragen und Bedenken erörtert werden.

I) Es handelt sich beim R.M.B. nicht im Geringsten um eine Religionsvermischung. Die Kreise, die eine solche betreiben, verkennen durchaus die Tatsache, dass in der religiösen Erneürung unserer Zeit alle Religionen und Konfessionen sich wieder auf ihre besonderen Grundlagen besinnen und ihr individülles Wesen kraftvoll ausgestalten. Das Ringen der Religionen miteinander wird deshalb nicht abnehmen, sondern eher zunehmen.

II) Trotz dieser Tatsachen glaubt der R.M.B an die Möglichkeit eines Zusammengehens zu praktischen Zwecken. Es steht erstens fest, dass im Geheimen ein stiller Zug den Religiösen zum Religiösen hinzieht, auch wenn jeder den anderen als Letzter ansehen muss. Und zweitens ist es unleugbare Tatsache dass trotz der Verschiedenheiten der Moral und trotz der verschiedenen religiösen Begründung der einzelnen Gebote des Sittengesetzes doch die entschiedene Ablehnung von Unsitte und Unzucht, Ungerechtigkeit und Vertragsbruch, Übervorteilung und Gewinnsucht, Ungeistlichkeit und Weltgebundenheit allen Religionen gemeinsam ist.

III) Die Aufgabe der Mission, zu der jede Geistesmacht sich verpflichtet fühlt, wird durch den R.M.B. nicht beseitigt, es wird im Gegenteil für die Auseinander- 
setzung und Werbung noch eine neü Möglichkeit geboten, insofern als beim $\mathrm{Zu}$ sammenarbeiten in unmittelbarem, persönlichem Geistesaustausch die Stärke des Glaubens der einzelnen Religionen sich bekunden kann. Kein Religiöser wird so die enge Fühlungnahme mit Andersglaubigen scheün, wenn er nur von der Kraft seines Glaubens wirklich überzeugt ist.

IV) Es handelt sich beim R.M.B. nicht nur um religiösen Pazifismus. "Friede um jeden Preis" ist überhaupt nicht das ausschlaggebende Ideal. Es muss vielmehr Recht und Gerechtigkeit um jeden Preis erkämpft werden. Wenn der religiöse Pazifismus das tut, dann steht er im Rahmen der Aufgaben eines R.M.B., denn dann liegt hier die Bemühung um ein Teilziel vor innerhalb des grossen Zieles der Erneürung der Weltkultur aus dem Geiste der Religionen.

V) Die Arbeit an der Versöhnung der absichtlichen Kirchen wird durch den R.M.B. nicht hinfällig. Er hofft aber, dass diese Bestrebungen die Notwendigkeit des gröseren Zieles der Vereinigung aller guten Willen in der Welt erkennen und dass sie ihre Freundschaftsarbeit vor allem im Hinblick auf die gemeinsame Bewältigung der Weltnot und die gemeinsame Neugestaltung des ganzen öffentlichen und zwischenstaatlichen Lebens betreiben.

VI) Der R.M.B. verkennt nicht die macht der realpolitischen Wirklichkeiten für das geschichtliche Geschehen, er ist aber überzeugt, dass Glauben und Gewissen ebenso starke wenn nicht noch stärkere Wirklichkeiten sind. Diese inneren Mächte verlangen jetzt gebieterisch Beachtung und Berücksichtigung. Sie können es nicht länger dulden, dass der Weltlauf allein durch das Geld und die brutale Gewalt beherrscht wird. Das innere Leben fängt jetzt an, so stark zu werden, dass es sich auch im ausseren Leben Geltung verschaffen und dass es seine Grundsätze sogar zum leitenden Prinzip einer Neugestaltung der Welt erheben muss. - So rechnet der R.M.B. auf diejenigen, die in die Waagschale der geschichtsbestimmenden Faktoren den Faktor der religiösen und sittlichen Wirklichkeit hineinwerfen müssen. Er rechnet auf diejenigen, die es um Glaubens- und Gewissens willen nicht aushalten, stille zu sitzen und die Welt dem Teufel zu überlassen.

Wer mithelfen will melde sich zum Beitritt beim Generalsekretariat des R.M.B. Offenbach a/M Waldstr. 124 pt, wo jede weitere Auskunft gerne erteilt wird. 